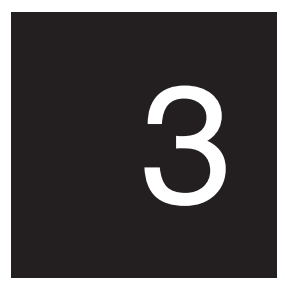

\title{
On the anthropology of modernity, or, some triumphs of culture over despondency theory
}

\section{Marshall Sahlins}

In the late 18th century, at the height of the European Enlightenment, the French philosophers invented the word 'civilisation' to refer to their own society-a usage that was quickly adopted in Britain. Among the other not too enlightening ideas that logically followed was the notion of a progressive series of evolutionary stages, beginning in 'savagery' and culminating in 'civilisation,' into which one could fit—and fix-the various non-Western peoples. The imperialism of the last two centuries has not reduced such enlightened contrasts between the West and the Rest. On the contrary the ideologies of 'modernisation' and 'development' that trailed in the wake of Western domination took their basic premises from the same philosophical regime. Even the critical arguments of the Left about indigenous 'dependency' and capitalist 'hegemony' could result in equally dim views of the historical capacities of non-Western peoples. As though these peoples had nothing to do with history, except to suffer from it.

\section{What has not been too enlightening}

In too many narratives of Western domination, the indigenous peoples appear merely as victims - neo-historyless peoples whose own agency disappeared more or less with their culture, the moment Europeans 
erupted on the scene. Indeed, as Margaret Jolly has pointed out, when Europeans change it is called 'progress', but when 'they' (the others) change, notably when they adopt some of our progressive attributes, it is a loss of their culture, some kind of adulteration. As the European folklore goes, before we came upon the inhabitants of the Americas, Asia, Australia or the Pacific islands, they were 'pristine' and 'aboriginal'. It is as if they had no historical relations with other societies, were never forced to adapt their existence. Rather, until Europeans appeared, they were 'isolated' - which just means that we were not there. They were 'remote' and 'unknown' — which means they were far from us, and we were unaware of them. Hence the history of these societies only began when Europeans appeared-an epiphanal moment, qualitatively different from anything that had gone before, and culturally devastating. The historical difference with everything pre-colonial was power. Exposed and subjected to Western domination, the less powerful peoples were destined to lose their cultural coherence, as well as the pristine innocence for which Europeans-incomplete and sinful progeny of Adam - so desired them.

Accordingly, one of the main academic consequences of the violence inflicted by the West was the 'despondency theory' that became popular in a variety of twentieth century literature relating to colonised peoples. Despondency theory was the logical precursor to dependency theory. But as it turned out - when the surviving victims of imperialism began to seize their own modern history-despondency was another not terribly enlightening idea of the power of Western 'civilisation'. Here is a good example from A.L. Kroeber's great 1948 textbook, Anthropology.

With primitive tribes, the shock of culture contact is often sudden and severe. Their hunting lands or pastures may be taken away or broken under the plough, their immemorial customs of blood revenge, headhunting, sacrifice, marriage by purchase or polygamy be suppressed, perhaps their holy places profaned or deliberately overthrown.

Resistance is crushed by firearms. Despondency settles over the tribes. Under the blocking-out of all old established ideals, without provision for new values and opportunities to take their place, the resulting universal hopelessness will weigh doubly heavy because it seems to reaffirm inescapable frustration in personal life also (1948:438-39).

A corollary of despondency theory was that the others would now become just like us-if they survived. The Enlightenment had already prepared for this eventuality by insisting on the universality of human reason and progress: a course of development that would be good-in 
all senses of the term-for the human species as a whole. In his Primitive Culture of 1871, E.B. Tylor showed the doom that awaited appreciation of cultural diversity by these theories of unilineal evolution, by endorsing - as an appropriate procedure for classifying societies in evolutionary stages - the immortal observation of Dr. Johnson that 'one set of savages is just like another.' A late classic of the genre was Walt Rostow's Stages of Economic Growth (1957), with its unilinear sequence of five developmental stages from 'traditional societies' to 'the age of high mass consumption.' (Rostow must have been among the first to perceive that the culmination of human social evolution was shopping.) Explicitly argued as an alternative to Marxist stages of progress, Rostow's thesis appeared as a mirror image, with the added advantage of turning left into right twice over. Common to many theories of development was a cheerful sense of cultural tragedy: the necessary disintegration of traditional societies that functioned, in Rostow's scheme, as a precondition for 'economic take-off'. Foreign domination was needed to accomplish this salutary destruction, since otherwise the customary relations of traditional production would set a ceiling on economic growth. By its own providential history, Europe had been able to develop itself, but according to Rostow, other peoples would have to be shocked out of their backwardness by an intrusive alien force. No revolutionary himself, Rostow could agree with Marx that in order to make an omelette one must first crack the eggs. Interestingly many peoples now explicitly engaged in defending their culture against national and international domination - the Maya of Guatemala and the Tukanoans of Colombia, for example (Warren 1992; Watanabe 1995; Jackson 1995) - have distanced themselves both from the bourgeois Right and the proletarian Left, refusing the assimilation pressures that would sacrifice their ethnicity to either the construction of the nation or the struggle against capitalist imperialism. Contrary to the evolutionary destiny the West had foreseen for them, the so-called savages will neither be all alike nor just like us.

In this vein, and as the century wears on, Max Weber's comparative project concerning the possibilities for capitalist development afforded by different religious ideologies seems increasingly bizarre. Not that it is by any means bizarre to talk of the cosmological organisation of pragmatic action. What seems increasingly weird is the way Weberians became fixated on the question of why one society or another failed to achieve this summum bonum of human history: 
capitalism. One American Sinologist said China during the Qing dynasty had come so very close. It is like asking why the New Guinea Highlanders failed to develop the spectacular potlach of the Kwakiutl people. A question the Kwakiutl social scientist might well ask, given how so close the New Guineans had come with their elaborate pig exchange ceremonies. Likewise the Christian missionaries' question of how Fijians in their natural state failed to recognise the true god. One might as well ask why European Christians did not develop the ritual cannibalism of Fijians. After all, they came so close.

What is perhaps more interesting, as it actually happened, is how Christianity was Fijianised. Local societies everywhere have attempted to organise the irresistible forces of the Western World System by something even more inclusive- their own system of the world, their own culture.

\section{The indigenisation of modernity}

This is a modern song of the Enga people of New Guinea, about capturing the power-knowledge of Europeans, the 'Red Men' in local parlance

When the time comes,

Our youngsters will feed upon their words,

After the Red Men drift away from this land,

Our youngsters, like honey birds,

After the Reds have gone,

Will suck the flowers,

While standing back here.

We will do like them,

We shall feed upon their deeds

Like honey-birds sucking flowers.

(Talyaga 1975:n.p.)

Reversing the real relations of exploitation and domination, these verses could easily be mistaken for the wistful fantasies of the powerless. Yet it would be wrong to suppose them motivated by selfcontempt or a sense of their impending doom. Everything about the modern ethnography of Highland New Guinea indicates that the sentiment of cultural usurpation-here so ambiguously figured as honey-birds feeding on the powers of banished White men-is the guiding principle of the Highlanders' historical action. Rather than despondency, it is a positive action towards modernity, premised on the Enga's assurance they will be able to harness the good things of 
Europeans to the development of their own existence. 'Develop-man' is the neo-Melanesian term for 'development,' but it would not be wrong to re-pidginise it back to English as 'the development of man', since the project to which it refers is the use of foreign wealth in the expansion of feasting, politicking, subsidising kinship and other activities that make up the local conception of a human existence. These are the activities that the working and warrior youth of the Enga are being urged to undertake. Rather than the death of tradition, the Enga thus express their confidence in a living tradition, a tradition that serves as a means and measure of innovation.

In anthropological terms, which is to say perceiving great things in little ones, this active appropriation by the Enga of the European power imposed upon them, is a local manifestation of a new planetary organisation of culture. Unified by the expansion of Western capitalism over recent centuries, the world is also being re-diversified by indigenous adaptations to the global juggernaut. In some measure, global homogeneity and local differentiation have developed together, the latter as a response to the former, in the name of native cultural autonomy. The new planetary organisation has thus been described as a 'Culture of cultures,' a world cultural system made up of diverse forms of life. As Ulf Hannerz put it: 'There is now a world culture, but we had better make sure we understand what this means. It is marked by an organisation of diversity rather than a replication of uniformity' (1990:237). Thus one complement of the new global ecumenicism is the so-called culturalism of very recent decades: the self-consciousness of 'culture' as a value to be lived and defended, that has broken out all around the Third and Fourth worlds. Ojibway, Hawaiians, Inuit, Tibetans, Amazonian peoples, Australian Aborigines, Maori people, Senegalese: everyone now speaks of their 'culture,' or some local equivalent, precisely in the context of national or international threats to the existence to that culture. This does not mean a simple and nostalgic desire for tiki ornaments and war clubs, or some such fetishised repositories of a pristine identity. Such a 'naive attempt to hold peoples hostage to their own histories,' as one anthropologist has said, would thereby deprive them of history (Turner 1987:7). What the self-consciousness of 'culture' does signify, is the demand of different peoples for their own space within the world cultural order. The focus of the Enga song above is not so much a refusal of the commodities and relations of the world system, but rather a desire to indigenise them. The project is the indigenisation of modernity. 


\section{Tradition and change}

The struggle of non-Western peoples to create their own cultural versions of modernity undermines the received Western dichotomy of tradition and change, custom and rationality—and most notably its twentieth century version of tradition and development. This tradition-change antithesis was already old by the time the philosophers of the Enlightenment took on the project of destroying entrenched superstition by progressive reason. It had been kicking around advanced European thought at least since Sir Francis Bacon proposed to smash the idols of the cave and the tribe by the exercise of rational-empirical wisdom-and thus rescue humanity from the metaphysical consequences of Original Sin. Modern versions of the same ideological hang-up notably include the theories of development economists in which, as we have seen, so-called tradition, supposedly burdened with irrationalities, appears as an obstacle to so-called development.

Paradoxically, almost all the cultures described as 'traditional' by anthropologists, were in fact neotraditional, already changed by Western expansion. In some cases this happened so long ago that noone, not even anthropologists, now debate their cultural authenticity. The Iroquois confederacy was by all accounts a post-contact developman, as were the Plains Indian cultures that flourished through the acquisition of the horse. For all that, were the Iroquois less Iroquoian or the Sioux less Souian? And nowadays, are not the Maori people Maori, the Fijians, Fijian? In Fiji today, Wesleyan Christianity is considered the 'custom of the land'. Margaret Jolly rightly wonders why church hymns and the Christian mass should not be considered 'part of Pacific tradition', given that they 'have been significantly remade by Pacific peoples, so that Christianity may appear today as more quintessentially a Pacific than a Western faith'. If Pacific peoples gloss over the distinction-so critical to the Western sensibilitybetween the colonial and the precolonial past, it is that they 'are more accepting of both indigenous and exogenous elements as constituting their culture' (Jolly 1992:53). Faced with this hybrid state of affairs, we might be advised to return to the indigenous daily routine of the average American man described some decades ago by Ralph Linton.

After breakfast our good man settles down to read the news of the day 'imprinted in characters invented by the ancient Semites upon a material invented in China by a process invented in Germany. As he 
absorbs the accounts of foreign troubles he will, if he is a good conservative citizen, thank a Hebrew deity in an Indo-European tongue that he is 100 percent American' (1936:329).

In Europe and the Peoples without History, Eric Wolf correctly pointed out that most of the world was a mix of the indigenous and the exogenous by the time Western anthropologists arrived. Imperialism had arrived first. Regrettably, in his effort to convince fellowanthropologists that they had never really known the pristine peoples they hankered after, Wolf neglected to draw the complementary conclusion concerning the cultural differences the ethnographers had nonetheless discovered and described. If the indigenous peoples were not without history, it was because they were not without their culture-which is also why their modern histories have differed.

In the late 18th century, the Hawaiian chiefs largely monopolised trade with the British and American vessels stopping for provisions and sandalwood while en route to China with furs from Northwest America. The chiefs, however, had distinctive economic demands, mainly for unique adornments and domestic furnishings, flashy goods that linked their persons to the sky and overseas sources of divine power, fashionable goods that could also differentiate them from their aristocratic fellows and rivals. Their Kwakiutl counterparts on the Northwest Coast were beginning a long economic history of a contrasting kind, demanding standardised items from the fur traders by the tens of thousands, items which eventually became Hudson's Bay blankets. Moreover, rather than hoarding their treasures as Hawaiian chiefs did, the Kwakiutl distributed their blankets (in potlatches) in ways that allowed them to correlate and measure their otherwise distinct claims to superiority. In contrast to the rather mundane woollen blankets that Kwakiutl demanded, Honolulu traders of Boston firms sent to America for de luxe articles: 'Everything new and elegant will sell at a good profit. Coarse articles are of no use.' The letter books of these traders are full of orders for fine calicoes, silks, shawls, and scarves 'in handsome patterns', superfine broadcloths and cashmeres; a whole catalogue of Polynesian splendours in a European idiom-commodities, moreover, from which most people were excluded. Unlike the Kwakiutl chiefs who were fashioning their pre-eminence out of common cloth, the Hawaiian élite were bent on unique projects of economic aggrandisement. But then, the Hawaiian chiefs were all more or less closely descended from the gods, and the main issue between them was how to turn these 
quantitative differences of genealogy into qualitative distinctions of standing. By contrast, the Kwakiutl chiefs already represented distinct and unrelated lineages, with different divine origins and powers. As heirs of unique ancestors and treasures, they used stock European goods in public fashion to make comparative representations of their worth, to turn their qualitative differences in genealogy into quantitative measures of rank. Accordingly the politics, economics and destinies of the Hawaiians and the Kwakiutl acquired different forms and fates in the nineteenth century. Their respective cultural traditions survived in the different ways they changed. Tradition is not the opposite of change.

\section{Corollary: money and markets, moralities and mentalities}

Everyone thought native Americans were finished long ago and yet modern ethnographers of the Cree nation are now talking about a 'cultural enhancement' or an 'indigenous affluence' that has actually been funded by the use of the market economy. They speak of a culturally-oriented project of development, one that reflects certain customary Cree ideas of 'the good life' by an explicit promotion of Cree 'culture', although their classic situation of dependency could still eventually be their downfall. In the meantime, the trappings of dependency could also be an empirical critique of the orthodoxy that money and markets are incompatible with the customs and kinship relations of so-called traditional societies. Indeed, Cree people find two-way radios useful in sustaining customary relations between kinsmen. Colin Scott found that snowmobiles and trucks likewise 'have increased [the] opportunities for sharing'. Human sharing is only an aspect of a cosmic cycle of exchange-that includes the animals who give themselves to the hunters and receive in turn their ritual rebirth—and snowmobiles have become part of an even larger economy than is dreamed of in the capitalist philosophy: a world system that includes both human beings and nature in social relations of personhood and interdependence. Over the centuries of increasing engagement in commodity production and exchange, Scott writes

[t]he structure and quality of sharing, of kinship, and of man-animal relations remain quite distinctively Cree and quite characteristically egalitarian. Generosity is normal and expected. The needs of an extended network of relatives are a primary and lifelong occupation. Social and personal renewal are found in the encounter of people and animals. Cree themselves take these relations to be fundamental definers of their humanity and their cultural identity (1984:77). 
The Cree culture has not simply persisted in spite of capitalism or because the people have resisted it. This is not so much a culture of resistance as the resistance of culture. Since Cree act in the world as social-historical beings, with their own cultural consciousness of themselves and of the objects of their existence, their experience of capitalism is mediated by the practice of their own form of life. Culture inhabits action. In the event, the capitalist forces are played out in a different cultural universe.

According to Marx, money destroys the archaic community because money becomes the community. It is as if, Freud complained, a person suddenly got a psyche when he drew his first pay check. In a book called Money and the Morality of Exchange, however, Maurice Bloch and Jonathan Parry collect a number of ethnographic examples to refute the idea. As against the idea that money gives rise to a particular world view - the unsociable, impersonal and contractual one we associate with it - they emphasise 'how an existing world view gives rise to particular ways of representing money' (1989:19). Money can very well be the servant of custom not its master. The destructive effects of markets and money on communities presuppose a separate 'economic' domain, as Bloch and Parry point out, an amoral sphere of transaction separated from the generosities of kith and kin. Where there is no structural opposition between the relationships of economy and sociability, where material transactions are ordered by social relations rather than vice versa, then the amorality we attribute to money need not result. Where the economy is embedded in society, say Bloch and Parry, 'monetary relations are rather unlikely to be represented as the antithesis of bonds of kinship and friendship, and there is consequently nothing inappropriate about making gifts of money to cement such bonds' (1989:19).

It follows that in certain structural conditions, money could actually increase kinship bonds: it could 'develop' the so-called traditional societies in the sense that they understand develop-man-as obtaining more and better of what they consider to be good things, such as anthropological reports from the New Guinea Highlands since the 1960s have reported. Benefiting from the market returns to migratory labour, coffee production and other cash-cropping, the great inter-clan ceremonial exchanges have flourished in recent decades as never before. Among the Enga, Chimbu, Hagen, Mendi, and others, the ceremonies have increased in frequency as well as in the magnitude of people engaged and goods transacted in them. Accordingly big-men 
are more numerous and powerful. Old clan alliances that had lapsed have been revived. Interpersonal kinship networks have been widened and strengthened. Money has been the means, rather than the antithesis, of community. High-value bank notes replace pearl shells as key exchange valuables, gifts of Toyota land cruisers complement the usual pigs, and large quantities of beer function as initiatory presents (adding certain celebratory dimensions to the customary festivities). Captured in reciprocal obligations and bridewealth payments, 'the money which circulates in exchanges is generally not "consumed" at all,' as Andrew Strathern noted of the Hageners, 'but keeps on circulating, through the momentum of debt and investment' (1979:546). Rena Lederman reports that among modern Mendi people the exchange obligations between clans and personal kin create 'a demand for modern currency far greater than the demand generated by existing market outlets' (1986:332). Hence the Mendi say they have the true exchange economy, by contrast to the mere 'subsistence economy' of white men (1986:236).

\section{Reversing centre and peripheries}

Cities are the favoured places of merantu, the customary journeys of the Menangkabau and other Indonesian men beyond the boundaries of their own culture, whence they return with booty and stories worthy of their manhood. The Malay community in Mecca is second in size only to that of the Arabs. Some remain on the haj for 10 years or more; some are delayed for years, returning via Africa or India (Provencher 1976). The Mexican villagers working in Redwood City, California, and the Samoans in San Francisco likewise intend to return, an eventuality for which they prepare by sending money back to relatives, telephone calls and periodic visits to their native places, by sending their children home for visits or schooling and otherwise maintaining their natal ties and building their status in their former and future home. Can Samoans, Malays, Oaxacans, Africans, Filipinos, Peruvians, Thais-the millions of people now cycling between the 'peripherae' and metropolitan centres of the modern world-systembe content to return to a bucolic existence 'after they've seen Paris'? Is it not true (as the medieval proverb goes) that Stadt Luft macht Frei? Or if not free, proletarians forever? However true in an earlier European history, today the huge phenomenon of circular migration is creating a new kind of cultural formation: a determinate community without entity, extending transculturally and often transnationally from a rural 
centre in the so-called Third World to 'homes abroad' in the metropolis, the whole united by the toing and-froing of goods, ideas and people on the move. 'The geographic village is small,' writes Uzzell of Oaxacan campesinos, 'the social village spreads over thousands of miles' (1979:343).

Taking shape as urban ethnic outposts of rural, 'tribal' or peasant homelands, these synthetic formations remained unrecognised as such by the Western social scientists studying them for a long time. Or rather in studying urbanisation, migration, remittance dependency, labour recruitment or ethnic formation, Western researchers presented a spectacle something like the blind men and the elephant, each satisfied to describe the cultural whole in terms of one or another of its aspects. No doubt the Euro-American history of urbanisation had a stranglehold on the anthropological imagination. The general presumption was that urbanisation must everywhere put an end to what Marx called the idiocy of rural life. Relations between people would become impersonal, utilitarian, secular, individualised and otherwise disenchanted and detribalised because of the very nature of the city as a complex social and industrial system,. Such was the trend in Robert Redfield's 'folk-urban continuum'. As the beginning and end of a qualitative change, countryside and city were structurally distinct and opposed ways of life. 'After the rise of cities,' Redfield wrote, 'men became something different from what they had been before' (1953:ix). British social anthropology of the period was hung up on the same dualist a priori. Max Gluckman was the father of the African version: 'The African in the rural areas and in town,' he said, ' is two different men' (1960:69).

Enlightenment was soon in coming. Explicitly taking on the folkurban continuum, Edward Bruner demonstrated the continuity of identity, kinship and custom between Toba Batak villages of highland Sumatra and their urban relatives in Medan. 'Examined from the structural point of view, the Toba Batak communities in village and city are part of one social and ceremonial system' (1961:515). Speaking more widely of Southeast Asia, Bruner wrote that 'contrary to traditional theory, we find in many Asian cities that society does not become secularised, the individual does not become isolated, kinship organisations do not break down, nor do the social relationships in the urban environment become impersonal, superficial and utilitarian' (1961:508). By the mid 1970s such observations had become common in the Latin American homeland of the folk-urban continuum as well 
as in ethnographies by Gluckman's colleagues and others throughout sub-Saharan Africa. As the gestalt shifted from the antithesis of the rural-urban to the synthesis of the 'translocal' cultural order, study after study groped for a suitable terminology. The scholars spoke variously of 'a bilocal society', 'a single social and resource system', 'a non-territorial community network', a 'common social field' uniting countryside and city, a 'single community spanning a variety of sites on both sides of the border', 'a single social field in which there is a substantial circulation of members' or some new species of the like.

What any and all these descriptions express is the structural complementarity of the indigenous homeland and the metropolitan 'homes abroad,' their interdependence as sources of cultural value and means of social reproduction. Symbolically focused on the homeland, whence its members derive their identity and their destiny, the 'translocal' community is strategically dependent on its urban outliers for material wherewithal. The rural order itself extends into the city, inasmuch as the migrants associate with each other in the urban context on the basis of their relationships at home. Kinship, community and tribal affiliations acquire new functions, and perhaps new forms, in the relationship among migrants: they organise the movements of people and resources, the care of homeland dependents, the provision of urban housing and employment. Insofar as people conceive their social being and their future in their native place, the material flows generally favour the homeland people. The indigenous order is sustained by earnings and commodities acquired in the foreign-commercial sector. But should we speak of 'remittances' as the foreign economic experts do? Epeli Hau'ofa has argued on occasion that this flow of money and goods is better understood by the norms of 'reciprocity,' since it reflects the migrants' obligations to homeland kin, even as it secures their rights in their native place. 'Reciprocity' as opposed to 'remittances' appropriately shifts the analytic perspective from a geographic village that is small to a social village spread over thousands of miles. Rather than lament the fate of a village that lives on 'remittances' one might, with Graeme Hugo, commend its success in reversing 'the parasitic function traditionally ascribed to cities' (1978:264). In spanning the historic divide between traditional and modern, the developmental distance between centre and periphery and the structural opposition of townsmen and tribesmen, the translocal community deceives a considerable body of enlightened Western social science. 
Indeed this capacity of indigenous peoples to move freely and improvise culturally obliges us to reconsider certain presuppositions about the precolonial order-presuppositions whose source, incidentally, could never have been ethnography but rather the folklore of the civilising mission. Typically the cultural scheme was universal, and in the spaces beyond, true human beings were other kinds of persons and powers, which need to be appropriated as a precondition of local society. From exploits that transcended the community borders, men-most often men-returned with trophies of war or the chase, with goods acquired in raid or trade, with visions, songs, amulets, potions and cults, things familiar or new that could be consumed, sacrificed, exchanged, given away or otherwise disposed of in order to reproduce and develop the indigenous form of life. If in spite of all this it could be thought these peoples were historyless or closed to innovation, it is probably because they sought novelty in the things they considered to have reproductive virtues, which might have been a new kind of valuable shell or magical formula, not exactly what a development-economist would consider a 'capital investment'. It follows that few if any of the peoples known to anthropology were culturally sui generis. Their supposed closure was, as I say, a myth that owes more to enlightened prejudices about their isolation than to any ethnographic observation. We have not been playing with amateurs, then, in games of construction-of-the-Other. This helps explain Marilyn Strathern's observation, regarding Melanesians: 'It has been something of a surprise for Europeans to realise that their advent was something less than a surprise' (1990:25).

It should not now come as a surprise that ethnographers working in New Guinea and Vanuatu, in Mexico, Indonesia and the Amazon Basin, have seen a certain continuity, or more precisely a develop-man, of ancient custom in the modern phenomenon of circular migration. Since 1858 certain Xhosa have been working in the mines and towns of southern Africa. Their crossing into the dangerous terrain is still explicitly conceived and ritually protected as an excursion of warfrom which they return with the booty of civilisation, to be celebrated as 'good and moral men' (McAllister 1980). In highland New Guinea too: 'Just as the blind Homer sang of the journeys and heroes of Troy, so recent Enga poets have praised their heroes and immortalised their deeds through images of commemorative chants' (Lacey 1985:93). This travelling tradition has seen exponential growth through the colonial and post-colonial periods, and their journeys now take Enga men to 
coastal towns and foreign lands, but even in pre-colonial days the heroes returned with means of cultural innovation and transformation. The whole highlands culture, as presently constructed, is a few centuries old or less, following the European expansion that brought the sweet potato into the Pacific.

\section{Culture is not disappearing}

It is possible that the translocal community will soon disappear as a cultural form. If the migrants settle permanently abroad, the structure might have a generational half-life, the attachments to the homeland dissolving with each city-born or foreign-born generation. However, in parts of Indonesia, Africa and elsewhere, circular migration has been going on for many generations. Reports from Nairobi in the 1980s echo observations in Java from 1916: the migrants were not being proletarianised. From a large review of anthropological literature on culture and development, Michael Kearney recently came to precisely that conclusion: 'migrants have not been proletarianised in any deeply ideological sense' (1986:352). However, here I am not concerned with the longevity of the form. What is of more interest is the on-going creation of new forms in the modern world Culture of cultures. Noone can deny that the world has seen an overall decrease of cultural diversity in the past five centuries. Indeed, anthropology was born out of the consciousness of the decrease as much as the appreciation of the diversity. There is no special reason now to panic about the death of culture.

Suppose for argument's sake we agree that Branislow Malinowski's Argonauts of the Western Pacific was the beginning of modern professional ethnography. If so, it is sobering to reflect that it opens with these words

[e]thnology is in the sadly ludicrous, not to say tragic, position, that at the very moment when it begins to put the workshop in order, to forge its proper tools, to start ready for work on its appointed task, the material of its study melts away with hopeless rapidity. Just now, when the methods and aims of scientific field ethnology have taken shape, when men [n.b.] fully trained for the work have begun to travel into savage countries and study their inhabitants—-these die away under our very eyes (1922:xv).

History studies past objects, but how many academic disciplines other than high-energy physics originated as the study of disappearing objects? Yet anthropologists can take heart. Another set of cultural 
forms has developed since the fifteenth century: hybrid forms, some of them space-defying or using the latest technology in creative projects of indigenising modernity. The discipline seems as well off as it ever was, with cultures disappearing just as we were learning how to perceive them, and then reappearing in ways we had never imagined.

The best modern heirs of the Enlightenment philosophers know this. I mean for example the West African intellectuals who argue, with Paul Hountondji (1994), that 'culture is not only a heritage, it is a project'. It is, as Abdou Touré insists, an African project, or set of projects, and not the universal march of reason proclaimed by the eighteenth century and still worshipped in the development religions of the twentieth.

That which the minority of [élite] leaders has voluntarily forgotten is Culture as a philosophy of life, and as an inexhaustible reservoir of responses to the world's challenges and it is because they brush aside this culture that they're able to reason lightly in terms of development while implying a scale of values, norms of conduct or models of behaviour transmissible from one society to another! (Touré 1994).

Touré's conclusion is that 'Africa is no longer subjected to the Western model of development for the simple reason that there is no longer a model of any worth.' Finally-enlightenment.

\section{Notes}

1 Another characteristic example

A village that is inwardly alive is proof against a government policy as well as against natural cataclysms neither of which affects its spiritual energies; but it cannot withstand the disintegrating forces of trade and commercial development, the stealthy invasion of money economy, the gradual weakening of its agricultural basis, of the tie that binds it to the soil - a tie which is but a part of the bond that unites man with man, the contact with the rest of the world. For these latter are destructive forces that kill not only the physical 1 element in the communal bases-agriculture to supply domestic needs-but also the two spiritual elements which underlie the village communityreligion and social unity — and with these kill the soul of the village (Boeke 1942:19).

2 As if in response to Rousseau's Second Discourse, Clifford Geertz writes: 'men unmotivated by the customs of particular places do not in fact exist, have never existed, and most important, could not in the very nature of the case exist' (1973:35; cf Sahlins 1993:12-13). 
3 Here is a modern song of the Enga people

When I have taken possession of them,

Of the great books of the lowlands,

I'll happily stride back

To Wabag, that land of mine,

Where the quiet stars go by.

It's my heritage, the land of my proud fathers,

There I'd make my home,

And there I'd settle,

There I'll settle,

Where the stars will pass over me,

With books firm in my hand.

(Talyaga 1975: Song 21)

\section{References}

Bloch, M., and Parry, J. (eds), 1989. Money and the Morality of Exchange, Cambridge University Press, Cambridge.

Boeke, J.H., 1942. The Structure of the Netherlands Indian Economy, Institute of Pacific Relations, New York.

Bruner, E., 1961. 'Urbanization and ethnic identity in North Sumatra', American Anthropologist, 63:508-521.

Geertz, C., 1973. The Interpretation of Cultures, Basic Books, New York.

Gluckman, M., 1960. 'Tribalism in modern British Central Africa', Cahiers d'Études africaines 1:55-70.

Hannerz, U., 1990. 'Cosmopolitans and locals in world culture', Theory, Culture and Society, 7(2-3):237-51.

Hountondji, P., 1994, 'Culture and development in Africa: lifestyles, modes of thought and forms of social organization', Paper prepared for the World Commission on Culture and Development, CCD-IV/94/REG, INF.9, UNESCO, Paris.

Hugo, G. J., 1978. Population Mobility in West Java, Second edition 1981, Gadjah Mada University Press, Yogyakarta.

Jackson, J., 1995. 'Culture genuine and spurious: the politics of Indianness in the Vaupés, Columbia', American Ethnologist, 22:3-27.

Jolly, M., 1992. 'Specters of inauthenticity', The Contemporary Pacific, $4(1): 49-72$.

Kearney, M., 1986. 'From the invisible hand to the visible feet: anthropological studies of migration and development', Annual Reviews of Anthropology, 15:331-61. 
Kroeber, A.L., 1948. Anthropology, Harcourt Brace, New York.

Lacey, R., 1985. 'Journeys and transformations: the process of innovation in Papua New Guinea', in M. Chapman (ed.), Modernity and Identity in the Island Pacific, Special issue of Pacific Viewpoint 26:81-105.

Lederman, R., 1986. What Gifts Engender: social relations and politics in Mendi, highland Papua New Guinea, Cambridge University Press, Cambridge.

Linton, R., 1936. The Study of Man, Appleton Century Crofts, New York.

Malinowski, B., 1922. Argonauts of the Western Pacific, Routledge and Kegan Paul, London.

McAllister, P.A., 1980. 'Work, homestead and the shades: the ritual interpretation of labour among the Gcaleka', in P. Mayer (ed.), Black Villages in an Industrial Society, Oxford University Press, Capetown.

Provencher, R., 1976. 'Shifts in the cycle of experience: Malay perceptions of migration', in D. Gullet and D. Uzzell (eds), New Approaches to the Study of Migration, Rice University Studies, Houston 62:63-71.

Redfield, R., 1953. The Primitive World and its Transformations, Cornell University Press, Cornell.

Sahlins, M., 1993. 'Goodbye to Tristes Tropes', Journal of Modern History 65:1-25.

Scott, C., 1984. 'Between "original affluence" and consumer affluence' in R.F. Salisbury and E. Tooker (eds), Affluence and Cultural Survival, The American Ethnological Society, Washington, DC:74-86.

Strathern, A., 1979. 'Gender, ideology and money in Mt Hagen', Man 14(3):530-48.

Strathern, M., 1990. 'Artefacts of history: events and the interpretation of images', in J. Sikala (ed.) Culture and History in the Pacific, The Finnish Anthropological Society, Transactions No.27, Helsinki:2544 .

Talyaga, K., 1975. Modern Enga Songs, Institute of Papua New Guinea Studies, Boroko, Port Moresby.

Touré, A., 1994. 'Minority culture, majority development' Paper prepared for the World Commission on Culture and Development, UNESCO CCD-IV/94/REG/INF.11, Paris.

Tylor, E.B., 1871. Primitive Culture, Murray, London. 
Turner, T., 1987. 'The politics of cultural survival', in B. Spooner (ed.), Conservation and Survival, Oxford University Press, Oxford.

Uzzell, D.J. 1979. 'Conceptual fallacies in the rural-urban dichotomy', Urban Anthropology 8:333-350.

Warren, K.B. 1992. 'Transforming memories and histories: the meaning of ethnic resurgence for Mayan Indians', in A. Stepan (ed.), Americas: new interpretive essays, Oxford University Press, New York:189-219.

Watanabe, J.M., 1995. 'Unimagining the Maya: anthropologists, others and the inescapable hubris of authorship', Bulletin of Latin American Research 14:25-45.

Wolf, E., 1982. Europe and the People Without History, University of California Press, Berkeley and Los Angeles. 